\title{
Poliandri di Kalangan Masyarakat Muslim: Studi Sosiologis di Kelurahan Bunut Kecamatan Kisaran Barat Kabupaten Asahan
}

\author{
Hasliza Lubis \\ Universitas Islam Negeri (UIN) Sumatera Utara \\ haslizalubis@gmail.com
}

\begin{tabular}{l|l|l}
\hline Received: 02 Januari 2020 & Revised: 20 Maret 2020 & Approved: 20 April 2020 \\
\hline
\end{tabular}

\begin{abstract}
The purpose of this research is to know the factors that cause the Muslims in Bunut village west Kisaran District Asahan Regency to do polyandry practice. The process of a wife's marriage is still valid marriage to her first husband. Wives get married to other man without any divorced or divorce proceedings because the wife is separated form the first husband. This research is a field study, researchers use qualitative debitor that use the interview method as primary data which then generates descriptive analytical data. Results of this research, after conducting the factors are influenced by economic factors, low levels of education, and lack of awareness of people's understanding of the law, the first husband is not responsible, the husband's work away from his wife, polygamy husband, high lust, and weak supervision of the Office of Religious Affairs (KUA) when the parties get married husband and wife. Regarding public awareness in Bunut about marriage belong is low so that they does not follow the rules in Islamic law, marriage law and compilation of Islamic law.
\end{abstract}

Keywords: Polyandry, muslim society, legislation, Islamic law

\begin{abstract}
Abstrak
Tujuan Penelitian ini adalah untuk mengetahui faktor-faktor yang menyebabkan masyarakat muslim Kelurahan Bunut Kecamatan Kisaran Barat Kabupaten Asahan melakukan poliandri. Proses pernikahannya istri masih terikat perkawinan yang sah dengan suami pertamanya. Istri melakukan pernikahan dengan pria lain tanpa adanya talak ataupun proses perceraian karena istri dalam kondisi terpisah dari suami pertama. Penelitian ini merupakan penelitian lapangan, peneliti menggunakan pendekatan kualitatif yang menggunakan metode wawancara sebagai data primer yang kemudian menghasilkan data deskriptif analitis. Hasil dari
\end{abstract}


penelitian ini menunjukkan bahwa faktor-faktor yang menjadi penyebab tersebut dipengaruhi oleh faktor ekonomi, rendahnya tingkat pendidikan dan kurangnya kesadaran pemahaman masyarakat mengenai hukum, suami pertama yang tidak bertanggung jawab, suami berangkat bekerja jauh dari istrinya, suami yang berpoligami, hawa nafsu yang tinggi, serta lemahnya pengawasan Kantor Urusan Agama (KUA) saat menikahkan para pihak yaitu calon suami dan istri. Mengenai kesadaran hukum masyarakat Bunut tentang perkawinan tergolong masih rendah karena tidak mengikuti aturan yang ada pada hukum Islam, UU Perkawinan maupun Kompilasi Hukum Islam.

Kata kunci: Poliandri, masyarakat muslim, undang-undang, hukum Islam

\section{Pendahuluan}

Datangnya Islam yang merupakan agama fitrah. Mensyariatkan perkawinan untuk menjadikan tujuan suatu hubungan yang harmonis antara lakilaki dan perempuan sesuai dengan syariat Islam. ${ }^{1}$ Untuk mencapai pengaturan rumah tangga dan keturunan yang terhormat maka jalannya adalah perkawinan. Karena tujuan dari perkawinan sifatnya jangka panjang sebagaimana melindungi martabat dan kehormatan dalam membina rumah tangga yang rukun, tentram dan bahagia. Subekti juga berpendapat perkawinan adalah pertalian sah dalam kurun waktu yang lama antar seorang pria dan wanita. ${ }^{2}$ Maka, manusia perlu suatu ikatan yang terhormat pula yang memiliki nilai. Di Indonesia, perkawinan telah sesuai dengan prinsip dan asas perkawinan yakni asas monogami, namun pada prakteknya sering juga ditemukannya perkawinan yang bersifat poligami bahkan ada juga poliandri.

Berbicara mengenai poliandri, hal serupa jauh sebelumnya sudah terjadi. Praktek poliandri banyak terjadi pada orang Eskimo, Oseanis, Toda ( daerah India selatan dan di beberapa negara Afrika dan Tibet). ${ }^{3}$ Menurut catatan sejarah, perkawinan yang semacam ini banyak terjadi di negara India daerah selatan dan utara dan di beberapa wilayah di Rusia. Di wilayah India, secara bersamaan kakak beradik boleh mengawini seorang wanita. Bila seorang kakak menikah seorang perempuan, saudara laki-laki ( adik laki-lakinya) yang lain juga boleh memiliki perempuan yang dikawini oleh kakaknya. ${ }^{4}$ Menurut sejarah telah berkembang di masyarakat Arab sebelum kedatangan Islam masyarakat Arab telah mengenal perkawinan semacam itu ar-rahthun (poliandri).

1 A. Ja’far, "Larangan Muslimah Poliandri: Kajian Filosofis, Normatif, Yuridis, Psikologis Dan Sosiologis," Al-Adalah 10, no. 3 (2012), h. 325.

2 Tengku Erwinsyahbana, "Sistem Perkawinan Pada Negara Hukum Berdasarkan Pancasila," Ilmu Hukum 10, no. 2 (2012). h. 167.

${ }^{3}$ Adil Abdul Mun'im Abu Abbas, Ketika Menikah Jadi Pilihan (Jakarta: Almahira, 2007). h. 157.

${ }^{4}$ Ahnan and Ummu Khoiroh, Poligami Di Mata Islam (Surabaya: Putra Pelajar, 2001). h. 160. 
Kondisi ini sangat memperhatikan dalam urusan perkawinan selama istri masih terikat perkawinan yang sah ataupun secara siri sampai kapan pun selagi belum dicerai suami maka, istri tersebut tidak boleh menikah dengan siapapun karena dia masih statusnya istri orang lain. Begitu juga dalam Islam, peraturan perundang-undangan dan KHI melarang adanya poliandri. Sesuai informasi yang peneliti dapat pada masyarakat Bunut terdapat 32 wanita di Kecamatan Kisaran Barat yang melakukan pernikahan tanpa adanya perceraian dari suaminya. Dari 32 wanita tersebut 15 diantaranya berada di Kelurahan Bunut yang merupakan subyek penelitian ini. Dalam kasus ini mereka beranggapan perkawinan terdahulu sudah berakhir dengan dasar apabila istri di tinggal suami dan keberadaannya tidak di ketahui maka wanita tersebut boleh menikah lagi.

Meskipun suatu perkawinan sudah di atur dalam undang-undang namun pada realita yang terjadi masyarakat tidak mengikuti peraturan yang ada. Masyarakat muslim Bunut tidak mengindahkan aturan-aturan perkawinan yang telah di atur sehingga kurangnya kesadaran hukum. Kajian ini bukanlah yang pertama diteliti. Hal ini terlihat dari jurnal yang di tulis oleh Syahrizal Abbas beliau membenarkan yang terjadi sekarang terdapat istri yang memiliki suami lebih dari satu orang dalam waktu bersamaan (poliandri) sebagai bukti adanya kasus cerai talak di Mahkmah Syar'iyah Jantho. ${ }^{5}$ Hal sama juga dilakukan oleh Makmur Syarif, beliau lebih mengkaji putusan pengadilan dengan dasar pertimbangan-pertimbangan hakim dalam memutuskan perkara. ${ }^{6}$ Berbeda dengan ini ada yang mengulas tentang pelarangan wanita poliandri yang mengkaji dari berbagai prespektif yaitu filosofis, normatif yuridis, psikologis dan sosiologis. ${ }^{7}$ Berlanjut dengan Rudianto Hutagalung beliau membahas akibat yang akan di terima dari seorang wanita yang melakukan pernikahan tanpa adanya talak dari suami. ${ }^{8}$ Kemudian, Misran juga membahas yang hasil penelitiannya lebih membahas pada suami yang tidak bisa memberikan nafkah lahir bathin sebagai faktor penyebab poliandrinya.' Walaupun titik fokus kajian yang di lakukan peneliti dengan Misran hampir sama tapi yang membedakan kajian ini bahwa banyak hal yang melatarbelakangi wanita yang berpoliandri.

Peneliti menggunakan pendekatan sosiologi hukum yaitu melihat bagaimana prilaku masyarakat dan hukum yang ada pada aspek kehidupan sosial.

5 Syahrizal Abbas and Datul Mutia, "Putusan Talak Raj"i Pada Kasus Poliandri: Analisis Hukum Islam Terbadap Putusan Hakim Mabkamah Syar'iyah Jantho Nomor 216/Pdt.G/2015/MS JTH," Samarah 3, no. 1 (2019): 205-222.

${ }^{6}$ Makmur Syarif, "Poliandri Pada Masyarakat Kabupaten Padang Pariaman: Studi Kasus Di Pengadilan Agama Pariaman," Kafa'ah 6, no. 2 (2016): h. 179-200.

7 Ja'far, "Larangan Muslimah Poliandri: Kajian Filosofis, Normatif, Yuridis, Psikologis Dan Sosiologis.”h. 325

8 Rudianto Hutagalung, "Praktik Poliandri Di Desa Pantai Cermin Kecamatan Tapung Kabupaten Kampar," JOM Fakultas Hukum 4, no. 1 (2017): h. 1-15.

${ }_{9}^{9}$ Misran and Muza Agustina, "Faktor-Faktor Terjadinya Poliandri Di Masyarakat (Studi Kasus Di Kabupaten Pidie Jaya)," Samarah 1, no. 1 (2017).h. 248-274 
Maka, penelitian ini menggunakan teori kesadaran hukum. ${ }^{10}$ Pendekatan penelitian ini yaitu kualitatif yang menghasilkan data dengan deskriptif analitis, yaitu data lapangan di dapat oleh responden dari prilaku masyarakat yang diperoleh langsung dari objeknya melalui penelitian. Responden adalah yang memberikan jawaban dari sekelompok orang atau masyarakat terhadap pertanyaan yang di ajukan peneliti terkait langsung dengan masalah praktek yang terjadi di Kelurahan Bunut kecamatan kisaran Barat Kabupaten asahan. Adapun instrument digunakan untuk pengumpulan data penelitian yaitu wawancara dan angket. Berdasarkan ini, penulis menganalisis data-data yang sudah diperoleh kemudian di paparkan dan di uraikan pada hasil-hasil penelitian.

Hal yang terjadi di Kelurahan Bunut mereka anggap suatu perbuatan yang sah dan boleh di lakukan. Mengingat akan pentingnya tentang perkawinan maka peneliti tertarik untuk mengetahui faktor-faktor apa yang menyebabkan masyarakat muslim di Bunut khususnya wanita melakukan poliandri. Dengan adanya kajian ini harapan penulis meningkatkan rasa kepedulian dan saling mengingatkan antar sesama masyarakat akibat dan bahaya wanita yang berpoliandri. Oleh karena itu, perlunya koordinasi agar terealisasi di masyarakat antar berbagai pihak untuk menciptakan kesadaran hukum bagi masyarakat mengenai perkawinan.

\section{Pembahasan}

\section{Hakikat Perkawinan}

Allah memberikan kelengkapan berupa nafsu biologis kepada manusia karena dalam kehidupan manusia nafsu juga penting. Untuk menyalurkan nafsu, Islam membimbing untuk menjaga sehingga nafsu tersebut bisa diarahkan kepada kebaikan yang diridhai Allah bukan dilampiaskan secara sembarangan. ${ }^{11}$ Lewat dorongan seksual terbentuklah keluarga yang menjadi fungsi penting, yaitu melahirkan keturunan caranya yaitu dengan perkawinan. Hal ini serupa dengan pendapat bahwa dengan jalan perkawinan dalam satu ikatan yang sah pada hakekatnya untuk menghalalkan terjadinya hubungan kelamin baik antara pria dan wanita.

Kata dasar dari kawin yaitu perkawinan yang berasal dari kata bahasa Arab ziwaj maknanya "kawin dan nikah". ${ }^{12}$ Mengumpulkan arti nikah menurut bahasa, sedangkan menurut syara berarti suatu akad dibolehkannya berkumpul setelah ditentukan rukun-rukun dan syarat sudah terpenuhi. Secara etimologi,

${ }^{10}$ Mukti Fajar ND and Yulianto Achmad, Dualisme Penelitian Hukum Normatif Dan Empiris (Yogyakarta: Pustaka Pelajar, 2013).h. 56.

${ }_{11}$ Ashadi Falih and Cahyo Yusuf, Akblak Membentuk Pribadi Muslim (Semarang: Aneka Ilmu, 1985).h. 58.

12 Ahmad Warson Munawwir, Kamus Al-Munawmir, cet ke-14 (Surabaya: Pustaka Progressif, 1997).h.146. 
perkawinan berarti persetubuhan. Ada pula yang mengartikannya perjanjian (alaqdu). ${ }^{13}$ Lewat dorongan seksual terbentuklah keluarga yang menjadi fungsi penting, yaitu melahirkan keturunan caranya yaitu dengan perkawinan. Hal ini serupa dengan pendapat bahwa dengan jalan perkawinan dalam satu ikatan yang sah pada hakekatnya untuk menghalalkan terjadinya hubungan kelamin baik antara pria dan wanita.

Adapun asas dan prinsip perkawinan memiliki enam kesimpulan yaitu

1. Membentuk keluarga yang bahagia dan kekal merupakan tujuan perkawinan

2. sahnya perkawinan di tentukan hukum agama dan kepercayaan masingmasing

3. prinsip monogami

4. Calon pasangan baik suami dan istri matang psikis dan mental.

5. Menyulitkan akan adanya perceraian

6. Keseimbangan akan hak dan kedudukan suami istri

Pernikahan dengan berawal dari tujuan yang baik akan berpengaruh pada keharmonisan rumah tangga. Dalam membentuk rumah ikatan pertama yaitu ijab Kabul. ${ }^{14}$ Ibadah dalam pernikahan bukan ditinjau secara sakral, tapi bermakna ibadah karena tujuan berkeluarga bukan hanya melanjutkan keturunan, tetapi juga melindungi kemapanan kemasyarakatan dan suatu martabat bagi pria dan wanita. Namun pada prakteknya, dalam suatu perkawinan seringkali terjadinya berbagai masalah, perselisihan, kekerasan pada hubungan suami istri dan penyebabnya tingkah suami kepada istri yang akhirnya perkawinan menjadi penjara atau belenggu bagi perempuan. Maka dalam membangun cita-cita keluarga tersebut, selain bersandar pada Alquran dan Hadis pernikahan juga harus berpedoman pada undang-undang. Karena, hukum perkawinan di Indonesia secara tegas telah di atur yang mana aturan-aturan tersebut harus di patuhi dan di laksanakan.

Dalam Islam tujuan perkawinan dapat di katakan untuk melanjutkan perkawinan, menjaga diri dari perbuatan yang di larang, mewujudkan kasih sayang dalam keluarga dengan menjamin ketentraman serta untuk membersihkan keturunan. ${ }^{15}$ Untuk mewujudkan tujuan perkawinan kehidupan rumah tangga yang sempurna tidaklah mudah. Cinta memainkan peranan yang penting dalam menjadi landasan kehidupan perkawinan, membentuk keluarga dan memelihara anak-anak. Diharapkan juga bahwa rumah tangga berjalan kekal sehingga menghindari terjadinya perceraian. Agar mengembangkan kepribadiannya di perlukan saling melengkapi dan mengisi masing-masing pihak

${ }^{13}$ M. Ali Hasan, Pedoman Hidup Berumah Tangga Dalam Islam, cet. ke-2 (Jakarta: Siraja, 2006). h. 11.

14 M. Zein Satria Effendi, Problematika Hukum Keluarga Islam Kontemporer Analisis Yudisrudensi Dengan Pebdekatan Usulhiyah) (Jakarta: Kencana, 2004). h. 96.

15 Abdul Aziz Muhamad Azzam and Abdul Wahhab Sayyed Hawwas, Fiqh Munakahat (Jakarta: Sinar Grafika Offset, 2011). h. 251. 
untuk mencapai kesejahteraan spiritual dan material serta hak dan kewajiban orang tua untuk memberikan perlindungan dan pendidikan anak-anak.

\section{Perkawinan Poliandri}

Praktek perkawinan wanita (istri) dan mempunyai beberapa pria (suami) merupakan arti dari pernikahan poliandri secara umum. ${ }^{16}$ Praktek ini banyak di jumpai di India bagian selatan dan utara serta beberapa wilayah Rusia serta Tibet. Akan tetapi, secara umum agama manapun tidak mengakui praktek perkawinan seperti ini dan dianggap sebagai penyimpangan sosial. ${ }^{17}$ Dalam perspektif filosofis, istri yang menikah untuk kedua kalinya tapi tidak adanya perceraian dari suaminya yang pertama merupakan bentuk pernikahan yang bertentangan dengan kodrat seorang wanita. Dan hukumnya haram karena statusnya masih sebagai istri dari suami pertama menurut prespektif normatif.

Perkawinan poliandri tidak sesuai dengan ketentuan perkawinan yang ada di Indonesia. Allah juga telah memberikan ketegasan dalam Q.S. An-Nisa' ayat 24 diterangkan tentang keharaman:
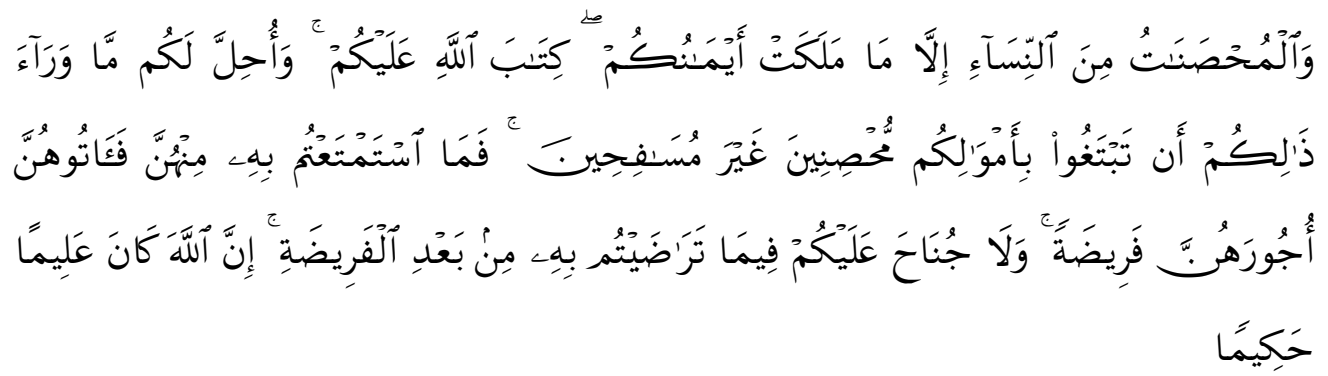

Dan (dibaramkan juga kamu mengawini) perempuan yang bersuami kecuali hamba sahaya perempuan (tawanan perang) yang kamu miliki. sebagai ketetapan-Nya atas kamu. Dan dihalalkan bagi kamu selain yang (perempuan-perempuan) yang demikian itu jikea kamu berusaba istri-istri dengan bartamu untuk menikabinya bukan untuk beriina. Maka karena kenikmatan yang telah kamu dapatkan dari mereka, berikanlah maskawinya kepada mereka sebagai suatu kewajiban. tetapi tiadak mengapa jika ternyata diantara kamu telah saling merelakannya, setelah ditetapkannya. Sesungguh, Allab Maha Mengetahui, Maha Bijaksana (Q.S. An-Nisa': 24)

Dengan tegas Q.S. An-Nisa' ayat 24 menyebutkan: janganlah kamu kawini wanita sedang bersuami. Dengan ketentuan ayat ini berupa larangan bagi wanita adalah untuk menikah dengan pria lain jika masih terkait perkawinan yang sah. Sedangkan dari sudut suami yang melakukan poligami maka juga

16 Warkum Sumitri and Dkk, Konfigurasi Fikih Poligini Kontemporer (Malang: UB Press, 2014). h. 3.

17 Zaitunah Subhan, Al Quran Dan Perempuan: Menuju Kesetaraan Gender Dalam Penafsiran (Jakarta: Kencana, 2015). h. 157. 
melarang berpoligami terhadap wanita yang memiliki suami. ${ }^{18}$ Adapun makna ayat tersebut memberikan isyarat bahwa wanita yang tidak boleh dinikahi seorang pria salah satunya adalah wanita yang memiliki suami. Larangan menikahi perempuan yang masih dalam status istri orang ataupun larangan menikahi wanita yang masih terikat tali pernikahan. Seorang wanita jika memiliki suami baik secara sah maupun siri haram menikah dengan siapapun. Bahkan perempuan yang sedang dalam tali ikatan perkawinan dengan seseorang dilarang dilamar baik secara terang-terang maupun sindiran walaupun akan di nikahi setelah si perempuan bercerai dengan suaminya dan telah selesai masa iddah-nya. Sesuai dengan ayat di atas Allah melarang wanita yang masih berstatus istri orang lain haram dinikahi. Islam melarang tegas bentuk perkawinan poliandri.

Begitu juga pun dalam Hadis sebagai dalil yang dilarang untuk poliandri adalah:

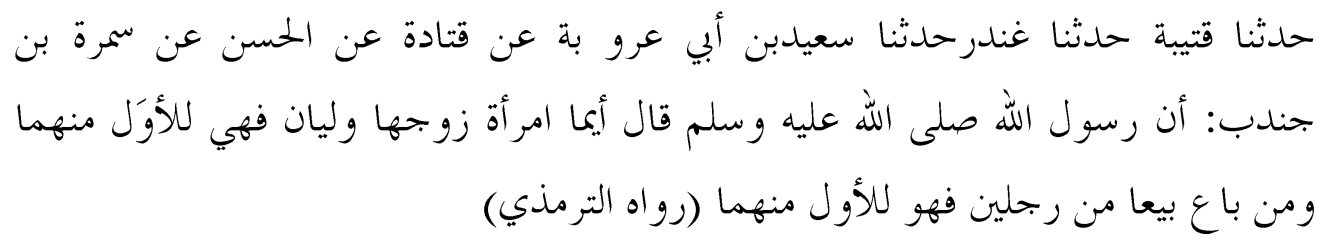

Telah meriwayatkan kepada kami 'Ghundar telah meriwayatkan kepada kami Sa'id bin 'Urubah dari Qatadah dari Hasan Sumarata bin Jundab bahwa Rasulullah Saw bersabda "siapa saja wanita yang dinikabi oleh dua orang wali, maka pernikahan yang sab wanita itu adalah bagi wali yang pertama dari keduanya". (HR. Al Tirmidzi). ${ }^{19}$

Hadis di atas secara tekstual membuktikan apabila seorang wanita yang dinikahi dua orang pria, wali yang menikahkan dua orang pria itu secara berurutan, maka akad nikah pertama yang dilakukan oleh wali itulah yang dianggap sah. Hadis ini memberikan penjelasan juga bahwa pernikahan wanita hanya sah jika dinikahi satu suami saja. ${ }^{20}$

Bukan hukum Islam saja, di Indonesia juga memberlakukan adanya larangan pernikahan wanita yang masih terikat perkawinan yang sah. Di Indonesia menganut asas monogami seperti pada Undang-Undang Nomor 1 Tahun 1974 tentang perkawinan, pasal 3 ayat (1) azasnya pada perkawinan seorang pria hanya boleh mempunyai seorang istri. Begitu juga sebaliknya. ${ }^{21}$

18 Sayuti Thalib, Hukum Keluarga Indonesia Berlaku Bagi Umat Islam (Jakarta: UI-Press, 2014).h. 61-62.

${ }^{19}$ Al-tirmidzi, Sunan Tirmidzi, juz 2 (Dar al-fikir, n.d.).h. 359.

20 Imam Asy-Syaukani, Bustamul Akbyat Mukbtashor Nailul Al Authar, jilid 3 (Pustaka Azzam, n.d.).h. 2185.

${ }_{21}$ Pagar, Himpunan Peraturan Perundang-Undangan Peradilan Agama Di Indonesia (Medan: Perdana Publishing, 2010).h. 16. 
Pada pasal 9 UUP tentang syarat perkawinan menegaskan bahwa seorang yang masih terikat tali perkawinan dengan orang lain tidak dapat kawin lagi kecuali dalam hal sebagaimananya disebutkan dalam pasal 3 ayat (2) dan pasal 4 UUD perkawinan. ${ }^{22}$ Apabila seorang istri hendak menikah untuk keduanya maka istri tersebut harus bercerai terlebih dahulu dengan suami pertamanya dengan syarat waktu tunggu telah selesai sebagaimana pasal $38 \mathrm{PP}$ No. 9 Tahun 1975 tentang pelaksanaan UU No. 1 Tahun 1974.

Dalam Kompilasi Hukum Islam di terangkan juga pada BAB IV pada pasal 40 huruf a dan b dilarangnya untuk melangsungkan perkawinan antara seorang pria dengan seorang wanita dalam keadaan tertentu yaitu wanita yang bersangkutan masih terikat satu perkawinan dan wanita yang masih berada dalam masa iddah dengan pria lain. ${ }^{23}$ Tidaklah sah pernikahan seorang istri yang masih terikat dengan perkawinan lalu kawin dengan pria lain sangat dilarang di Indonesia dan tidak diizinkan karena melanggar aturan negara baik hukum positif dan hukum Islam. $^{24}$

Di dalam bukunya Thalib, beliau juga memaparkan bahwa dalam pelaksanaan di tengah masyarakat dikenal beberapa bentuk perkawinan yaitu : ${ }^{25}$

1. Perkawinan monogami adalah perkawinan pria dan seorang wanita sebagai istrinya. Seorang wanita dan seorang pria sebagai suaminya, tanpa ada perempuan lain yang menjadi madunya.

2. Perkawinan poligami lawan dari monogami merupakan bantuk perkawinan seorang suami memiliki seorang istri lebih dari 1 dalam waktu yang sama.

3. Perkawinan bigami merupakan seorang lelaki menikahi 2 wanita atau lebih yang dalam waktu yang sama dengan saudara wanita yang di nikahi.

4. Perkawinan poliandri merupakan perkawinan seorang perempuan yang bersuami dua orang atau lebih dalam waktu yang bersamaan.

Pendekatan Islam, untuk mensejahterakan keluarga merupakan bisnis utama yaitu membangun komunikasi yang baik. Dalam Alquran untuk penataan keluarga, melindungi keluarga di kaitkan dengan ketakwaan keluaga kepada Allah dalam setiap kondisinya. ${ }^{26}$ Saat ini kemajuan zaman yang semakin kompleks mempengaruhi hidup berkeluarga. Kemajuan zaman yang disertai dengan perkembangan nilai-nilai, juga mau tidak mau mempengaruhi penghayatan hidup

22 Muhammad Amin Sunna, Himpunan Undang-Undang Perdata Islam Dan Peraturan Pelaksanaan Di Negara Hukum Indonesia (Jakarta: PT. Raja Rafindo Persada, 2004).h. 330.

${ }_{23}$ Pagar, Himpunan Peraturan Perundang-Undangan Peradilan Agama Di Indonesia.h. 117.

${ }_{24}$ Muhammad Syarifuddin, dkk. Hukum Perceraian, cet. ke-2 (Bandung: Sinar Grafika, 2014).h. 117.

${ }^{25}$ Muhammad Thalib, Orang Barat Berbicara Poligami (Yogyakarta: Wihdah Press, 2004).h. 2329.

${ }^{26}$ Muhammad Al Juari and Muhammad Abdul Hakim Khayyal, Membangun Keluarga Qur'ani (Panduan Untuk. Wanita Muslimah) (Jakarta: Amzah, 2005).h. 3. 
berkeluarga. Dalam kemajuan zaman itu, ada nila-nilai positif yang berupa kesadaran akan martabat manusia, kesadaran etika, kesadaran gender dan lainlain. Selain itu ada nilai-nilai yang merendahkan martabat hidup perkawinan, seperti poligami, perceraian, perselingkuhan, dan kekerasan dalam berkeluarga dan aneka macam persoalan lainnya yang mengakibatkan seorang wanita berpoliandri. Sebagai tindakan antisipasinya, perlu diambil tindakan untuk mengatasi tantangan hidup berkeluarga tersebut.

\section{Kesadaran Hukum Terhadap Aturan Pernikahan}

Dalam bermasyarakat aturan di kehidupan manusia bukan sebagai hanya kelengkapan dasar tetapi aturan itu dapat diwujudkan. Adanya peraturanperaturan yang mengatur ketertiban masyarakat dan masyarakat juga harus mentaati. Masalahnya apakah aturan dan fungsi yang tercantum di peraturan hukum efektif di dalam masyarakat tersebut.

Hukum bukan sekedar kebutuhan struktur kenegaraan, tapi kebutuhan masyarakat di suatu negara. Masyarakat tidak jauh dari hadirnya hukum. Hukum memenuhi sebagai kebutuhan sosial, ekonomi, dan kultural masyarakat. Di masyarakat ada dua fungsi hukum, pertama sebagai sarana kontrol sosial untuk menjaga masyarakat agar tetap pada struktur tingkah laku yang diterima. Kedua, sebagai sarana dalam melakukan perubahan sosial tujuannya adanya perubahanperubahan yang di masyarakat. ${ }^{27}$

Jika dilihat dari pandangan individu ke sosial pernikahan wanita yang masih terikat perkawinan sah dengan pria lain terjadi karena lemahnya kontrol sosial di dalam masyarakat Kelurahan Bunut Kecamatan Kisaran Barat. Masyarakat kurang mampu dalam memberikan pemahaman terhadap ketentuan hukum yang ada di Kelurahan Bunut tidak berjalan dengan baik sebab faktor dukungan dari masyarakat kurang berfungsi sehingga gejala sosial seperti praktik perkawinan wanita terjadi.

Suatu kapasitas hukum mengharapkan hukum untuk diciptakannya atau dilahirkannya keadaan atau situasi hukum yang direncanakan merupakan suatu efektifitas hukum. kalau sebagian besar target sasaran mentaati suatu aturan hukum yang berlaku, maka dapat dikatakan efektifitas hukum yang bersangkutan efektif. Cara kerja hukum yaitu dengan memberikan aturan dan paksaan kepada masyarakat agar mentaati hukum yang ada. Oleh karena itu, kaidah hukum peraturan yaitu aparat penegak hukum, sarana atau fasilitas yang digunakan, kesadaran masyarakat serta kebudayaan yang dapat mempengaruhi hukum tersebut.

27 Abdurrahman Muslan, Sosiologi Dan Metode Penelitian Hukum (Malang: UMM Press, 2009).h. 24-25. 
Untuk mencapai standar kesadaran hukum di masyarakat maka ada faktor-faktor yang mendasari yaitu ${ }^{28}$ adanya pengetahuan tentang hukum, hal ini berkaitan dengan mana tindakan yang diperbolehkan atau di larang oleh hukum. Dengan kata lain, tiap orang harus mengetahui aturan-aturan yang sudah di tetapkan hukum baik tertulis maupun tidak tertulis. Hukum dikatakan efektif apabila faktor-faktor yang mempengaruhi hukum berfungsi dengan sebaikbaiknya. Ukuran efektifnya suatu hukum bisa dilihat dari prilaku masyarakat efektif atau tidaknya suatu peraturan perundang-undangan. Peraturan perundang-undangan atau suatu hukum akan efektif apabila masyarakat prilakunya sesuai dengan apa yang di harapkan oleh peraturan perundangundangan tersebut untuk mencapai tujuan yang dimaksud, jika tujuan yang di harapkan terlaksana di masyarakat berarti efektivitas hukum atau peraturan perundang-undangan telah dicapai.

Contoh pada kasus kajian ini bahwa dalam aturan Kompilasi Hukum Islam (KHI) maupun hukum Islam selama wanita masih memiliki status suami orang lain ia tidak boleh melakukan menikah atau menerima pinangan dari pria lain. Jika hal ini terjadi maka pernikahan kedua seorang istri dapat dibatalkan. Tetapi kenyataan masyarakat khususnya wanita tersebut tidak mengindahkan aturan yang ada dikarenakan rendahnya pendidikan maka pengetahuan mereka juga rendah.

Selanjutnya, adanya pemahaman tentang hukum, berkaitan dengan informasi isi dan tujuan dari peraturan suatu hukum. Seperti pentingnya makna dan tujuan pernikahan yang diatur secara terperinci dan lengkap dalam hukum Islam dan negara. Dalam pasal 8 UUP, Pasal 70 Komplikasi Hukum Islam serta pasal 30 KUHP telah mengatur tentang pokok-pokok perkawinan mengenai ketentuan rukun dan syarat ditetapkan oleh hukum negara dan agama. Namun, masih terdapat masyarakat yang belum paham akan perkawinan yaitu mengenai aturan-aturan yang boleh dan tidak boleh untuk dinikahi.

Adanya sikap hukum yaitu memberikan penghargaan kepada hukum dengan cara menerima hukum merasakan bahwa jika hukum ditaati akan memberikan manfaat atau keuntungan. Namun, sikap yang terlihat dari wanita yang masih mempunyai ikatan perkawinan tidak memperdulikan statusnya sebagai seorang istri tidak peduli dengan syarat-syarat yang menjadi sahnya suatu perkawinan. Sebagai contoh pada tulisan Miti Yarmunida, jika bercerai dilakukan di pengadilan perbuatan hukum akibat perceraian akan terjamin. Manfaatnya memiliki bukti-bukti yang sah dan otentik dari perceraiannya, atau jika salah satu suami/istri ingin melangsungkan pernikahan dengan orang lain

${ }_{28}$ Achmad Ali, Menguak Teori Hukum (Legal Theory) Dan Teori Peradilan (Yudicial Prudence) (Jakarta: Kencana Prenadia Group, 2009). h. 298. 
dapat di proses dengan cepat karena memiliki bukti sah yang menunjukkan tidak dalam ikatan pernikahan dengan orang lain. ${ }^{29}$

Adanya pola prilaku hukum, di sini kaitannya dengan kesadaran hukum dilihat dari aturan yang berlaku atau tidak di masyarakat. Rendahnya kesadaran hukum jika tingkat kesadaran masyarakat mengenai hukum itu tinggi maka masyarakat akan patuh terhadap ketentuan peraturan yang dibuat. Begitu juga sebaliknya, jika kesadaran mengenai hukum masyarakat rendah, maka derajat kepatuhan juga rendah. Permasalahan kesadaran hukum masyarakat terkait faktor-faktor apakah hukum yang berlaku mereka mengetahui, memahami, mentaati, dan menghargai sudah dengan ketentuan. Kesadaran hukum itu kaitannya dengan pengetahuan, pemahaman, serta pengharapan terhadap hukum.

Begitu juga mengenai perkawinan, untuk mewujudkan tantangan masyarakat yang di cita-citakan masyarakat luas juga ikut peran terhadap aturan negara tentang tata hukum perkawinan beralaskan cita hukum bangsa Indonesia yang telah diatur. ${ }^{30}$ Maka perlu dilaksanakan sosialisasi mengenai aturan undangundang perkawinan kepada publik untuk memupuk pengetahuan masyarakat akan pentingnya tata hukum perkawinan. Rendahnya kesadaran hukum masyarakat Bunut mengenai aturan perkawinan seharusnya dari lembaga Kementrian Agama mengadakan suatu penyuluhan dan diseminasi kepada masyarakat yang implikasinya dengan persoalan terkait dengan hakikat perkawinan. Dengan memberikan himbauan untuk wanita jika hendak menikah atau bercerai hendaknya segera diurus segala administrasi untuk menjaga hak seorang wanita atau istri agar tidak ada menimbulkan masalah di kemudian hari.

\section{Faktor-faktor penyebab Poliandri Di Kelurahan Bunut Kecamatan Kisaran Barat Kabupaten Asahan}

Pernikahan poliandri biasanya memang sangat jarang terungkap di khalayak ramai akan tetapi ditemukannya perkawinan yang disebut poliandri pada masyarakat Bunut. Padahal suami pertama belum dan tidak pernah menceraikan istrinya ataupun mengucapkan talak terhadap istrinya. Pernikahan tersebut di laksanakan secara resmi dan tanpa sepengetahuan suami pertama, pernikahan poliandri ini hanya di ketahui oleh beberapa pihak keluarga.

Awalnya pernikahan antara suami istri sudah cukup lama, seorang suami masih sanggup untuk memenuhi tanggung jawabnya kepada istri dan anak. Beriringnya waktu pernikahan tersebut terjadinya perselisihan seperti mempunyai banyak hutang, suami yang sering pergi meninggalkan istri sehingga

\footnotetext{
${ }^{29}$ Miti Yarmunida and Busra Febriyani, "Kedudukan Talak Di Pengadilan Perspektif Siyasah Syar'iyah," Al-Istinbath 4, no. 2 (2019): h. 260.

${ }^{30}$ Ali Imron, Hukum Perkawinan Islam Di Indonesia (Semarang: CV. Karya Abadi, 2015).h. 1.
} 
terjadinya kekerasan dalam rumah tangga. Dari masalah yang ada, istri meminta cerai dari suaminya tetapi suaminya menolak. Karena tidak tahan dengan masalah tersebut istri mengajukan permohonan untuk menggugat cerai atau mendaftarkan perceraian di Pengadilan Agama. Setelah mendaftarkan perceraian wanita tersebut melangsungkan pernikahan dengan pria lain beberapa hari kemudian. Hal ini menjadi perbincangan di kalangan masyarakat Bunut karena pada saat melangsungkan pernikahan yang kedua wanita tersebut belum resmi bercerai dengan suami pertamanya masih terikat pernikahan dengan suami yang pertama. Pernikahan yang ke dua dilangsungkan secara sirri atau di bawah tangan dan hanya disaksikan keluarga dari masing-masing pihak calon mempelai. ${ }^{31}$

Peneliti juga melakukan wawancara dengan pembantu pencatat nikah KUA di Kecamatan Kisaran Barat berdasarkan pengalaman yang pernah mengawinkan seorang istri karena ditinggal suaminya. Beliau memberikan informasi mengenai praktek perkawinan ini. Adapun hasil tanya jawab dengan Bapak Syaiful Gunawan sebagai pembantu pencatat nikah KUA bahwa alasanalasan pembantu pencatat nikah menikahkan seorang istri yang telah ditinggal suaminya karena mereka mengatakan bahwa suaminya pergi merantau keluar negeri dan sama sekali tidak adanya kabar berita dari sang suami, suami mereka yang tidak memberikan nafkah lahir ataupun batin. Dengan alasan itu mereka menganggap bahwa suami tidak peduli dengan istrinya berarti pernikahannya sudah berakhir, dari faktor pendukung itulah para istri nekat untuk dinikahkan dengan pria lain. ${ }^{32}$

Secara keseluruhan, hasil informasi dari wawancara langsung dari narasumber. Kebanyakan karena mereka bekerja sebagai ibu rumah tangga, sedangkan gaji dari suami yang tidak dapat memenuhi kebutuhan rumah tangga, sehingga istri mencari nafkah sendiri. Ada yang menjadi Tenaga Kerja Wanita (TKW), ada menjadi tukang cuci, buruh dan lain-lain. Sedangkan suami yang kurang memberi kasih sayang terhadap istri, kurang rasa nyaman dan harmonis di dalam rumah tangga, suami yang sering mabuk-mabukan, narkoba, sering memukul istri, jarak dengan suami berjauhan dan kurangnya iman sebagai kontrol sosial mengakibatkan istri melakukan poliandri. Untuk menunjang faktor yang terjadi diperlukannya wawancara dengan beberapa responden yaitu kepala lurah, kepala lingkungan, tokoh masyarakat, para wanita yang melakukan pernikahan tersebut serta masyarakat yang mengetahui informasi tersebut. Dari sampel yang di dapat dari responden terlihat faktor-faktor penyebab poliandri di kalangan masyarakat muslim di Kelurahan Bunut yaitu:

${ }^{31}$ wawancara dengan Bapak Rudi selaku Kepala Lingkungan Bunut, 13 Juni 2019.

32 Wawancara dengan Bapak Syaiful Gunawan selaku Pembantu Pencatat Nikah,18 Juni 2019. 


\section{Faktor ekonomi}

Pada umumnya dari pengamatan peneliti dan pandangan dari informan mengenai pernikahan wanita yang masih terikat perkawinan sah yang terjadi di Kelurahan Bunut adalah karena adanya tata berpikir perbuatan yang sudah tidak asing bagi wanita yang melakukan poliandri. Wanita yang melakukan poliandri ini cenderung dilakukan dari kalangan keluarga biasa dan kurang mampu dalam hal perekonomian.

Tidak di pungkiri bahwa faktor utama untuk penunjang dalam rumah tangga adalah kestabilan ekonomi yang harus dijaga. Stabil atau tidaknya ekonomi dapat memberikan pengaruh ada keharmonisan keluarga. ${ }^{33}$ Ekonomi berkaitan dengan nafkah yang di hasilkan oleh keluarga. Keluarga dipandang sebagai pemenuhan segala kebutuhan tiap anggota keluarga tersebut. Setelah terjadinya akad, maka tugas suami memberikan nafkah untuk istrinya. Di dalam rumah tangga seorang istri bertugas memelihara dan mendidik anak, dan seorang suami bertugas memenuhi kebutuhan dan memberi nafkah keluarga selama ikatan perkawinan masih berjalan.

Hasil dari wawancara peneliti dengan Ibu Dija selaku wanita yang melakukan pernikahan poliandri faktor sulitnya akan ekonomi tidak ada perubahan kondisi waktu dengan waktu yang lama dari ekonominya. ${ }^{34}$ Ketika seseorang mengalami krisis finansial dalam keluarga, ia berusaha mencari solusi dengan alasan hidupnya lebih baik lagi jika ia menikah dengan pria lain. ${ }^{35}$ Pada akhirnya istri mencari jalan pergi dengan meninggalkan suaminya ke daerah lain. Lalu, di daerah barunya dimana ia tinggal, istri melakukan perkawinan yang kedua dengan pria lain yang dapat memberikan perlindungan atau pemenuhan kebutuhan ekonominya namun dengan suami pertama tidak adanya perceraian.

\section{Rendahnya Pendidikan dan Kurangnya Kesadaran Pemahaman Masyarakat Tentang Hukum}

Cara berpikir seseorang di pengaruhi tingkat pendidikan. Semakin berilmu seseorang, maka seseorang akan berhati-hati untuk bertindak. Tingkat pendidikan dilihat ada dua sisi yaitu pendidikan umum maupun agama. Seseorang yang tidak berilmu akan mudah melakukan sesuatu tanpa mengetahui hukum. Dan ketika di beritahu hukum, seseorang tidak mengindahkan hukum tersebut berarti tergolong menyepelekan hukum. Faktor ini di pengaruhi tingkat pendidikan karena masih ada warga yang tidak pernah merasakan pendidikan. ${ }^{36}$

33 Kahirul Abror, "Poligami Dan Relevansinya Dengan Keharmonisan Rumah Tangga (Studi Kasus Di Kelurahan Rajabasa Bandar Lampung)," Al-Adalah 13, no. 2 (2016).h. 234.

${ }^{34}$ Wawancara dengan Ibu Dija pelaku poliandri, 25 maret 2019.

${ }^{35}$ Wawancara dengan Ibu Afni pelaku poliadri, 25 maret 2019.

36 Wawancara dengan Muhammad Binu tokoh masyarakat, 13 juni 2019. 
Dari hasil wawancara dengan Ibu Fika salah satu pelaku wanita yang poliandri beliau memberikan alasan melakukan perkawinan tanpa adanya perceraian dari suami pertama karena mereka sudah lama tidak bersama dan suami tidak pernah memberi kabar sehingga beliau beranggapan sama dengan cerai dan melakukan prosedur perceraian sangat merepotkan di pengadilan. ${ }^{37}$

Masih terdapat masyarakat yang tidak sadar dan paham mengenai pentingnya perkawinan yang dicatatkan. perkawinan yang dicatatkan dipandang sebagai sekedar administrasi tidak disadari dari segi manfaat dari pencatatan perkawinan. Masih ada anggapan masyarakat bahwa tanpa perceraian yang resmi terhadap perkawinan pertama, tetap bisa melaksanakan perkawinan yang kedua. Masyarakat tidak sadar bahwa selain undang-undang mengatur perkawinan juga ada hukum pidana yang dapat menjerat. Rendahnya tingkat pendidikan yang pelaku peroleh mengakibatkan mereka tidak paham akan peraturan perundangundangan mengenai prosedur perkawinan dan perceraian yang benar. Sehingga mengakibatkan mereka melakukan perkawinan poliandri yang menurut mereka jika sudah dilakukan ijab kabul maka perkawinan mereka sudah dinyatakan sah.

\section{Suami Pertama Tidak Bertanggung jawab}

Hasil wawancara peneliti dengan narasumber bahwa pihak suami melalaikan kewajiban sebagai suami dengan tidak memberi nafkah kepada istri baik jasmani yaitu memberi untuk biaya hidup maupun rohani. Dalam kasus Ibu Rika karena suami yang sudah tua dan sering sakit-sakitan sehingga tidak sanggup memberi nafkah lahir dan batin mengakibatkan ketidakharmonisan di dalam rumah tangga sehingga Ibu Rika melakukan poliandri. ${ }^{38}$ Dalam kasus yang lain juga tercatat seorang istri karena suami jarang di rumah serta sering memukuli istri, sering mabuk-mabukan mengakibatkan tidak harmonis di dalam rumah tangga. ${ }^{39}$ Selain itu juga, suami yang terkena jerat kasus narkoba yang mengakibatkan suami tidak bertanggungjawab sebagai suami. Sehingga istri memilih meninggalkan suaminya dan menikah lagi dengan pria lain. ${ }^{40}$

Pengertian tidak bertanggung jawab dalam hal ini, bukan sekedar tanggung jawab dari segi nafkah tapi dalam pemberian kebutuhan keluarga lainnya. Kondisi yang terjadi di anggap berarti suami tidak melaksanakan kewajiban sebagaimana tugasnya suami. Akibat dari sikap suami yang tidak peduli dengan istri dan anaknya, sehingga antara suami istri terjadi hubungan yang tidak harmonis dan istri yang tidak sabar dengan mudahnya meninggalkan suami lalu menikah dengan laki-laki tanpa sepengetahuan suaminya. Aspek kurang harmonis kurangnya keharmonisan di dalam rumah tangga, menjadikan faktor istri melakukan poliandri.

\footnotetext{
${ }^{37}$ Wawancara dengan Ibu Linda pelaku poliandri, 1 April 2019.

38 Wawancara dengan Ibu Rika Pelaku Poliandri, 11 Juni 2019.

${ }^{39}$ Wawancara dengan Ibu Numen Pelaku Poliandri, 2 April 2019.

${ }^{40}$ Wawancara dengan Ibu Widia Pelaku Poliandri, 2 April 2019.
} 


\section{Suami Berangkat Bekerja Jauh Dari Istrinya}

Suami bekerja jauh sehingga meninggalkan istri hal ini menyebabkan istri berselingkuh dengan pria lain dan melaksanakan perkawinan dengan perkawinan yang kedua dilakukan secara siri. Istri merasa kebutuhan seksual tidak terpenuhi akibat suami yang bekerja jauh. Akhirnya melakukan poliandri karena jarak dengan suami yang sangat jauh, suami yang jarang pulang karena bekerja di luar daerah dan istri tidak terpenuhi hasrat biologisnya.

Dalam kasus Ibu Afni karena jarak dengan suami sedangkan suaminya bekerja di kalimantan sebagai supir jadi suami jarang pulang mengakibatkan Ibu Afni melakukan poliandri. Hal ini sesuai dengan pernyataan Ibu Afni bahwa dia melakukan perkawinan lagi tanpa adanya ucapan talak dari suami pertamanya karena suami jauh dan pergi sudah lama. ${ }^{41}$ Suami yang sering bepergian keluar kota ataupun luar negeri karena suami bekerja. Hal inilah penyebab faktor mereka poliandri padahal masih dalam ikatan perkawinan yang sah.

\section{Suami yang Berpoligami}

Sesuai dengan informasi yang di dapat dari Ibu Satyah akibat suami bekerja jauh beliau sebagai istri merasakan kecewa dan ke tidak keadilan karena suaminya menikah lagi atau melakukan pernikahan poligami (dengan cara nikah sirri) dengan wanita lain. ${ }^{42}$ Sesuai informasi yang di dapat dari Ibu Fika beliau juga merasakan hal yang sama karena suami yang di nikahinya ternyata sudah menikah lagi degan wanita lain. ${ }^{43}$ Tetapi dalam kasus ini seorang istri yang melakukan poliandri sebelum adanya keputusan resmi pengadilan agama ataupun masih dalam proses mengajukan gugatan. Namun saat bersamaan sebelum adanya proses dari pengadilan istri tersebut melakukan perkawinan kedua (poliandri) padahal belum ada perceraian dari pengadilan.

\section{Hawa Nafsu yang Tinggi}

Sebagaimana seperti keluarga lainnya, kebutuhan bukan hanya nafkah lahir, melainkan kasih sayang, perhatian, serta pemenuhan biologis. Apalagi bepergian suami dalam kurun waktu yang tidak sebentar mengakibatkan nafkah batin istri tidak terpenuhi sehingga istri mencari solusi dengan alasan hidupnya akan lebih baik jika ia menikah dengan pria lain. Hasil wawancara dengan Bapak Rudi beliau mengatakan bahwa manusia harus menahan hawa nafsu yang dapat merugikan dirinya sendiri. Perkawinan poliandri terjadi karena tidak dapat mengontrol hawa nafsu yang tidak terpenuhi dari suami pertama. Suaminya

\footnotetext{
${ }^{41}$ Wawancara dengan Ibu Afni Pelaku Poliandri, 25 Maret 2019.

42 Wawancara dengan Ibu Satyah Pelaku Poliandri, 25 Maret 2019.

${ }^{43}$ Wawancara dengan Ibu Fika, Pelaku Poliandri, 11 Juni 2019.
} 
berada jauh istri yang tidak terpenuhi hasrat biologisnya hal inilah istri memilih menikah lagi dengan pria lain. ${ }^{44}$

Hasil wawancara yang di lakukan peneliti hal sama juga di rasakan oleh Ibu Jannah, Ibu Siti, dan Ibu Susi suami atau istri yang merantau maka istri mencari alternatif lain untuk menyalurkan nalurinya sehingga istri melakukan pernikahan lagi (poliandri) di tempat ia bekerja tanpa jatuh talak dari pihak suami pertama. Seseorang suami ataupun istri yang telah sah akan merasa kesulitan jika pelayanan batin (hubungan suami istri) tidak didapatkan karena suatu keadaan mereka untuk berpisah.

\section{Kurangnya Pengawasan Kantor Urusan Agama (KUA) Saat Menikahkan Para Pihak}

Dari daftar registrasi pernikahan untuk melangsungkan pernikahan bahwa semua syarat-syarat yang diajukan sudah dipenuhi dan pernikahan keduanya tercatat sebagai perawan dan jejaka. Sesuai dengan penyampaian pelaksana tugas kepala kecamatan simpang empat oleh Bapak Dahmuk selaku pihak KUA bahwa kami tidak mengetahui jika istri masih terikat perkawinan dengan suaminya, jika dari saksi ataupun hadirin ada yang berbicara kejadian hal tersebut, maka pernikahan tidak dapat dilangsungkan. ${ }^{45}$

Kelalaian pihak KUA pada saat menikahkan para pihak yaitu tidak menanyakan terlebih dahulu perkawinan para pihak dan tidak menanyakan akta cerai kepada duda atau janda. Jika di pandang dari hukum positif Indonesia, perceraian dan perkawinan tersebut tidak diakui dan tidak sah berdasarkan hukum yang berlaku. Terdapat tidak adanya persamaan yang dikatakan Pak Kadi terhadap tindakan mengawinkan pasangan yang tidak memiliki akta cerai dengan pengakuan dari pelaku perkawinan tanpa akta cerai di Kelurahan Bunut.

Selain faktor-faktor di atas peneliti melakukan wawancara dengan Bapak Syaiful Gunawan menambahkan selaku pembantu pencatat nikah KUA di Kecamatan Kisaran Barat menjelaskan alasan seorang istri berani menikah lagi yang di tinggal suaminya ada beberapa faktor yaitu: ${ }^{46}$

a. Faktor yang menjadi kebiasan di masyarakat, jika seorang suami meninggalkan istrinya terlalu lama dan tidak meninggalkan kabar, maka istri tersebut memiliki anggapan berarti sudah terjadi perceraian.

b. Faktor nafkah lahir dan batin, seorang suami yang pergi merantau meninggalkan istrinya sehingga lupa akan kewajibannya tidak memberikan istri nafkah lahir ataupun batin.

\footnotetext{
${ }^{44}$ Wawancara dengan Bapak Rudi selaku Kepala Lingkungan, 13 Juni 2019

45 Wawancara dengan Bapak Damhuk selaku Kepala Kua Kecamatan Simpang Kawat,18 Juni 2019

${ }^{46}$ Wawancara dengan bapak Syaiful Gunawan Pembantu Pencatat Nikah Kecamatan Kisaran Barat,18 Juni 2019
} 
c. Kurang pengetahuan masyarakat mengenai undang-undang perkawinan dan aturan-aturan syariat Agama.

d. Kurangnya ada hubungan komunikasi untuk mempertahankan rumah tangga.

\section{Penutup}

Apabila seorang istri melakukan perkawinan kedua dengan pria lain akan tetapi masih belum bercerai dengan suami pertamanya maka secara sosiologis di katakan poliandri. Hukumnya adalah haram. Wanita yang melakukan poliandri semuanya tidak mengikuti aturan yang ada pada hukum Islam, UU Perkawinan maupun Kompilasi Hukum Islam. Hal ini ditemukannya dari penelitian bahwa faktor-faktor yang menjadi penyebab poliandri di kalangan masyarakat muslim Kelurahan Bunut Kecamatan Kisaran Barat Kabupaten Asahan yaitu: pertama, ekonomi karena hal yang harus dijaga kestabilan dari keluarga dalam berumah tangga yaitu suami harus mampu memberikan nafkah. Kedua, rendahnya pendidikan dan kurangnya kesadaran pemahaman masyarakat untuk kesadaran hukum karena rendahnya tingkat pendidikan yang pelaku peroleh mengakibatkan mereka tidak paham akan peraturan perundang-undangan mengenai prosedur perkawinan akan peraturan perundang-undangan tentang prosedur perkawinan dan perceraian yang benar. Ketiga, suami pertama tidak bertanggung jawab yang menyebabkan rumah tangga tidak harmonis. Keempat, suami berangkat bekerja jauh dari istrinya hal ini membuka peluang istri selingkuh sehingga melakukan poliandri. Kelima, suami yang berpoligami akibat dari suami yang menikah lagi membuat istri menikah lagi juga. Keenam, hawa nafsu yang tinggi karena istri memerlukan suami untuk memenuhi hasrat biologisnya. Ketujuh, kurangnya pengawasan Kantor Urusan Agama (KUA) saat menikahkan para calon suami dan istri. Dalam hal ini perlunya mengadakan penyuluhan dari ulama dan tokoh masyarakat kepada masyarakat terkait dengan hakikat perkawinan. Memeriksa dengan teliti terutama aparat atau penghulu yang berwenang mengenai rukun dan syarat sahnya suatu perkawinan agar tidak ada kesalahan-kesalahan mengenai bentuk perkawinan yang diperbolehkan dan perkawinan yang dilarang.

\section{Daftar Pustaka}

Abbas, Adil Abdul Mun'im Abu. Ketika Menikah Jadi Piliban. Jakarta: Almahira, 2007.

Abbas, Syahrizal, and Datul Mutia. "Putusan Talak Raj'i Pada Kasus Poliandri: Analisis Hukum Islam Terbadap Putusan Hakim Mabkamah Syar'iyah Jantho Nomor 216/Pdt.G/2015/MS-JTH.” Samarah 3, no. 1 (2019): 205-22.

Abror, Kahirul. "Poligami Dan Relevansinya Dengan Keharmonisan Rumah Tangga (Studi Kasus Di Kelurahan Rajabasa Bandar Lampung)." Al-Adalah 13, no. 2 (2016). 
Ahnan, and Ummu Khoiroh. Poligami Di Mata Islam. Surabaya: Putra Pelajar, 2001.

Al-tirmidzi. Sunan Tirmidzi. Juz 2. Dar al-fikir, n.d.

Ali, Achmad. Menguak Teori Hukum (Legal Theory) Dan Teori Peradilan (Yudicial Prudence). Jakarta: Kencana Prenadia Group, 2009.

Asy-Syaukani, Imam. Bustamul Akbyat Mukbtashor Nailul Al Authar. Jilid 3. Pustaka Azzam, n.d.

Azzam, Abdul Aziz Muhamad, and Abdul Wahhab Sayyed Hawwas. Fiqh Munakahat. Jakarta: Sinar Grafika Offset, 2011.

Effendi, M. Zein Satria. Problematika Hukum Keluarga Islam Kontemporer Analisis Yudisrudensi Dengan Pebdekatan Usulhiyah). Jakarta: Kencana, 2004.

Erwinsyahbana, Tengku. "Sistem Perkawinan Pada Negara Hukum Berdasarkan Pancasila." Ilmu Hukum 10, no. 2 (2012).

Falih, Ashadi, and Cahyo Yusuf. Akblak Membentuk Pribadi Muslim. Semarang: Aneka Ilmu, 1985.

Hasan, M. Ali. Pedoman Hidup Berumah Tangga Dalam Islam. Cet. ke-2. Jakarta: Siraja, 2006.

Hutagalung, Rudianto. "Praktik Poliandri Di Desa Pantai Cermin Kecamatan Tapung Kabupaten Kampar.” JOM Fakultas Hukum 4, no. 1 (2017): 1-15.

Imron, Ali. Hukum Perkawinan Islam Di Indonesia. Semarang: CV. Karya Abadi, 2015.

Ja'far, A. "Larangan Muslimah Poliandri: Kajian Filosofis, Normatif, Yuridis, Psikologis Dan Sosiologis." Al-Adalah 10, no. 3 (2012).

Juari, Muhammad Al, and Muhammad Abdul Hakim Khayyal. Membangun Keluarga Qur'ani (Panduan Untuk. Wanita Muslimah). Jakarta: Amzah, 2005.

Misran, and Muza Agustina. "Faktor-Faktor Terjadinya Poliandri Di Masyarakat (Studi Kasus Di Kabupaten Pidie Jaya)." Samarah 1, no. 1 (2017).

Munawwir, Ahmad Warson. Kamus Al-Munawmir. Cet ke-14. Surabaya: Pustaka Progressif, 1997.

Muslan, Abdurrahman. Sosiologi Dan Metode Penelitian Hukum. Malang: UMM Press, 2009.

ND, Mukti Fajar, and Yulianto Achmad. Dualisme Penelitian Hukum Normatif Dan Empiris. Yogyakarta: Pustaka Pelajar, 2013.

Pagar. Himpunan Peraturan Perundang-Undangan Peradilan Agama Di Indonesia. Medan: Perdana Publishing, 2010. 
Subhan, Zaitunah. Al Quran Dan Perempuan: Menuju Kesetaraan Gender Dalam Penafsiran. Jakarta: Kencana, 2015.

Sumitri, Warkum, and Dkk. Konfigurasi Fikih Poligini Kontemporer. Malang: UB Press, 2014.

Sunna, Muhammad Amin. Himpunan Undang-Undang Perdata Islam Dan Peraturan Pelaksanaan Di Negara Hukum Indonesia. Jakarta: PT. Raja Rafindo Persada, 2004.

Syarif, Makmur. "Poliandri Pada Masyarakat Kabupaten Padang Pariaman: Studi Kasus Di Pengadilan Agama Pariaman." Kafa'ah 6, no. 2 (2016): 179-200.

Syarifuddin, Muhammad. Hukum Perceraian. Cet. ke-2. Bandung: Sinar Grafika, 2014.

Thalib, Muhammad. Orang Barat Berbicara Poligami. Yogyakarta: Wihdah Press, 2004.

Thalib, Sayuti. Hukum Keluarga Indonesia Berlaku Bagi Umat Islam. Jakarta: UIPress, 2014.

Yarmunida, Miti, and Busra Febriyani. "Kedudukan Talak Di Pengadilan Perspektif Siyasah Syar'iyah." Al-Istinbath 4, no. 2 (2019): 253-66. https://doi.org/10.29240/jhi.v4i2.1020. 
20 | Al-Istinbath: Jurnal Hukum Islam, Vol.5, No.1, 2020

Halaman sengaja dikosongkan 